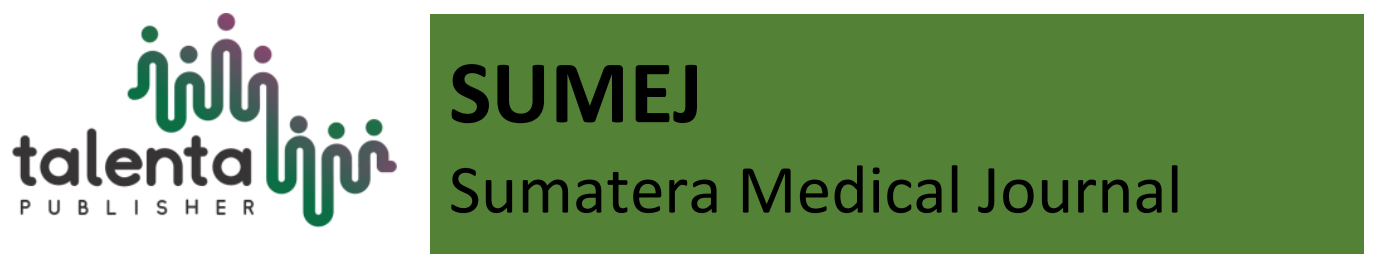

\title{
RISK FACTORS OF CONGENITAL ANOMALIE AT HAJJ ADAM MALIK GENERAL HOSPITAL AND UNIVERSITY OF NORTH SUMATERA HOSPITAL IN 2017-2019
}

\author{
R. P. Mukti', G. N. Yanni' \\ 1. Faculty of Medicine, Universitas Sumatera Utara, Medan, North Sumatera, Indonesia \\ 2. Department Staff of Pediatrics, Faculty of Medicine Universitas Sumatera Utara, Medan, North \\ Sumatera, Indonesia
}

\begin{abstract}
Background. Congenital abnormalities or congenital abnormalities are abnormalities that have existed since birth that can be caused by genetic and non genetic factors. The study of congenital abnormalities is called dysmorphology. Congenital abnormalities are one of the biggest contributors to death and morbidity in neonates, infants, and children. There were 7.9 million cases of congenital abnormalities and 3.3 million premature deaths due to congenital abnormalities in the world in 2013. In Southeast Asia it is estimated that cases of congenital abnormalities numbered 1,946,606 cases each year in 2013 according to WHO. In 2018, more than 8 million babies worldwide are born every year with congenital abnormalities. In the United States nearly 120,000 babies are born with congenital abnormalities each year. The cause of fetal congenital abnormalities due to genetic and non-genetic factors. Single gene mutations, balance disorders due to chromosomal abnormalities, and multifactorial abnormalities are included in genetic factors. Non-genetic factors can be caused by teratogen drugs (drugs, chemicals, infections, and maternal diseases that affect the fetus) and radiation. There are 5 risk factors that influence the occurrence of fetal congenital abnormalities, namely genetic, socioeconomic and demographic factors, environment, infection, and nutritional status. Aim. To determine the risk factors for congenital abnormalities in newborns at the Haji Adam Malik General Hospital and the University Hospital of North Sumatra in 2017-2019. Method. The design used by researchers uses a cross-sectional approach. The sample used was Patients with Congenital Abnormalities who were in the Human Rights Hospital and USU Hospital in 2017-2019. Result. The most influential risk factors for fetal abnormalities are maternal age, disease history, infectious history, and poor nutritional status. There are no results that can prove that the history of pregnancy affects the occurrence of fetal congenital abnormalities.
\end{abstract}

Keyword: Congenital Disorders, Haji Adam Malik General Hospital, University of North Sumatra Hospital.

Received 19 February 2020 | Revised 20 July 2020 | Accepted 10 August 2020

\footnotetext{
${ }^{*}$ Corresponding author at: Faculty of Medicine, Universitas Sumatera Utara, Medan, North Sumatera, Indonesia 


\section{Introduction}

Congenital or congenital abnormalities are abnormalities that have existed since birth that can be caused by genetic and non-genetic factors. Scientists who study the underlying disorder are called dysmorphology [1].

Congenital abnormalities are structural, functional, and metabolic disorders that occur at birth and cause mental or physical disabilities and can also cause death of newborns. Congenital abnormalities are mild and some are severe. There are 4,000 cases of fetal malformations, some of which can be treated and others not treatable, which then leads to the death of a newborn [2].

Congenital abnormalities can be caused by several things, namely chromosome or gene disorders, environmental factors (nutritional deficiencies, infectious diseases, maternal health conditions, teratogenic drugs, alcohol, pollutants, etc.), and genetic complexes, but there are also unknown causes. The number of cases of congenital abnormalities is quite a lot. WHO data shows that there are 7.9 million cases of congenital abnormalities each year and 3.3 million premature deaths due to congenital abnormalities in the world. In Southeast Asia it is estimated that there are 1,946,606 cases of congenital disorders annually. In Indonesia, the prevalence of congenital abnormalities is 59.3 per 1,000 live births [3].

\section{Methods}

The data used are secondary data obtained through medical records of newborns at the Haji Adam Malik General Hospital and North Sumatra University Hospital in January 2017 - March 2019. The sample used is total (total sampling). Affordable population in this study are all newborns who have congenital abnormalities at the Haji Adam Malik General Hospital Medan and Medan North Sumatra University Hospital in January 2017 - March 2019.

\section{Results}

Characteristics of mothers giving birth to babies with congenital fetal abnormalities at the Adam Malik Hajj General Hospital and the University Hospital of North Sumatra in 2017-2019 can be seen in the table below.

Table 4.1 Distribution of Congenital Abnormalities Based on Maternal Age in HAM

\begin{tabular}{lll}
\hline Age & Frequency & $\%$ \\
\hline $18-25$ y.o. & 20 & 30,8 \\
$25-40$ y.o. & 45 & 69,2 \\
\hline Total & 65 & 100
\end{tabular}


Table 4.2 Distribution of Congenital Abnormalities Based on Maternal Age at USU Hospital

\begin{tabular}{lcc}
\hline Age & Frequency & $\%$ \\
\hline $18-25$ y.o. & 12 & 44,4 \\
$25-40$ y.o. & 15 & 55,6 \\
\hline Total & 27 & 100 \\
\hline
\end{tabular}

Based on Table 4.1 and Table 4.2, it can be seen that the highest proportion of maternal age is age $25-40$ years $65.21 \%$ and lowest age is $18-25$ years $34.78 \%$. Age $25-40$ years is a productive age so many mothers who experience pregnancy and childbirth at that age. The results of research by Conway et al. at St. Christian Hospital for Children in 2002-2007 stated that mothers who gave birth to babies with fetal abnormalities most in the age group 25-34 years [4].

The research of Taksande et al (2010) proves that maternal age 21-30 occurs 152 pregnancies that cause fetal congenital abnormalities, if compared with maternal age $<20$ or $>30$ only 17 pregnancies cause fetal congenital abnormalities [5].

The results of this study are in accordance with research conducted by Sofian (2012) which is the age of the mother above 30 years and will be even higher at the age of 40 years and over. Whereas Manuaba (2012) states that age at risk of having Down syndrome is the age above 35 years $[6,7]$.

Table 4.3 Distribution of the Occurrence of Fetal Congenital Abnormalities by Age of Pregnancy at RSUP HAM

\begin{tabular}{lcc}
\hline Age of Pregnancy & Frequency & $\%$ \\
\hline $33-35$ months & 22 & 33,84 \\
$36-39$ months & 43 & 66,15 \\
\hline Total & 65 & 100 \\
\hline
\end{tabular}

Table 4.4 Distribution of the Occurrence of Fetal Congenital Abnormalities by Age of Pregnancy at USU Hospital

\begin{tabular}{lll}
\hline Age of Pregnancy & Frequency & $\%$ \\
\hline $33-35$ months & 7 & 25,92 \\
$36-39$ months & 20 & 74,07 \\
\hline Total & 27 & 100 \\
\hline
\end{tabular}


Based on Table 4.3 and Table 4.4 it can be seen that the proportion of mothers giving birth to babies with fetal abnormalities based on the highest gestational age is $36-39$ weeks $68,47 \%$ and the lowest is $33-35$ weeks $31.52 \%$.

The results of this study are consistent with research by Prabawa (1998) in Dr. Kariadi Semarang, stated that the highest proportion of gestational age is enough months (37-40 weeks) which is $67.7 \%$ [8].

Table 4.5 Distribution of Congenital Abnormalities Based on Gestation Rates at RSUP HAM

\begin{tabular}{lll}
\hline Gestation & Frequency & $\%$ \\
\hline 1 & 17 & 26,2 \\
2 & 33 & 50,8 \\
3 & 14 & 21,5 \\
4 & 1 & 1,5 \\
\hline Total & 65 & 100 \\
\hline
\end{tabular}

Table 4.6 Distribution of Congenital Abnormalities Based on Gestation Rates at USU Hospital

\begin{tabular}{lll}
\hline Gestation & Frequency & $\%$ \\
\hline 1 & 10 & 37,0 \\
2 & 12 & 44,4 \\
3 & 5 & 18,5 \\
\hline Total & 27 & 100 \\
\hline
\end{tabular}

Table 4.7 Distribution of the Occurrence of Fetal Congenital Abnormalities by Number of Partus in RSUP HAM

\begin{tabular}{lll}
\hline Partus & Frekuensi & $\%$ \\
\hline 0 & 23 & 35,4 \\
1 & 31 & 47,7 \\
2 & 11 & 16,9 \\
\hline Total & 65 & 100,0 \\
\hline
\end{tabular}


Table 4.8 Distribution of the Occurrence of Fetal Congenital Abnormalities by Number of Partus in USU Hospital

\begin{tabular}{lll}
\hline Partus & Frekuensi & $\%$ \\
\hline 0 & 12 & 44,4 \\
1 & 12 & 44,4 \\
2 & 3 & 11,1 \\
\hline Total & 27 & 100,0
\end{tabular}

Table 4.9 Distribution of Congenital Abnormalities Based on Abortion Rates in RSUP HAM

\begin{tabular}{lll}
\hline Abortus & Frekuensi & $\%$ \\
\hline 0 & 53 & 81,5 \\
1 & 12 & 18,5 \\
\hline Total & 65 & 100,0 \\
\hline
\end{tabular}

Table 4.10 Distribution of Congenital Abnormalities Based on Abortion Rates in USU Hospital

\begin{tabular}{lll}
\hline Abortus & Frekuensi & $\%$ \\
\hline 0 & 23 & 85,2 \\
1 & 4 & 14,8 \\
\hline Total & 27 & 100,0 \\
\hline
\end{tabular}

Based on Tables 4.5 - 4.10, it was found that the Gestation number was 27 patients (29.3\%), Gestation 2 was 45 patients (48.9\%), and Gestation> 320 patients (21.7\%). Partus 0 rates were 35 patients (38\%), Partus 143 patients (46.7\%), and Partus 2 were 14 patients (15.2\%). Abortion rate 076 patients $(82.6 \%)$ and Abortion rate 116 patients $(17.3 \%)$.

Research Glinianaia et al (2017), proves that there is little possibility of fetal congenital abnormalities in the second pregnancy if the first pregnancy has a fetal congenital abnormality. However, the thought of parents who plan to have children certainly thinks that they will experience fetal congenital abnormalities in the second pregnancy, but that is not proven or is less likely [9]. 
Table 4.11 Distribution of Congenital Abnormalities Based on History of Mother Disease in RSUP HAM

\begin{tabular}{lll}
\hline History of Mother Disease & Frequency & $\%$ \\
\hline Yes & 40 & 61,53 \\
No & 25 & 38,46 \\
\hline Total & 65 & 100 \\
\hline
\end{tabular}

Table 4.12 Distribution of Congenital Congenital Abnormalities Based on History of Mother Disease in USU Hospital

\begin{tabular}{llc}
\hline History of Mother Disease & Frequency & $\%$ \\
\hline Yes & 13 & 48,1 \\
No & 14 & 51,9 \\
\hline Total & 27 & 100 \\
\hline
\end{tabular}

Based on Table 4.11 and Table 4.12 it can be seen that the proportion of mothers giving birth to infants with fetal abnormalities based on the History of Maternal Disease is 53 (57.6\%) and Mothers who have no history of the disease are 39 (42.39\%).

Early pregnancy infections such as viruses (rubella, cytomegalovirus, herpes simplex, varicella-zoster), syphilis and toxoplasmosis can cause denervation of fetal structures and result in birth defects. Varicella-zoster infection has an estimated incidence of 1.6 per 100,000 births and is reported to be around $0.4 \%-2 \%$ during the first 20 weeks of pregnancy. In Northern Europe and the United States the prevalence of syphilis infection is around $0.02 \%$ and $4.5 \%$. In the United States alone the incidence of syphilis infection peaked in 1991 around 107 per 100,000 live births and decreased to 11.2 cases per 100,000 live births in 2002 [10].

The results of the study by Liu et al (2015), stated that mothers who have type 1 or 2 diabetes have increased 2/10 compared to women who have no history of diabetes. Although the increase in the occurrence of fetal congenital abnormalities is only $2 / 10$, preconception treatment is highly recommended for mothers who have DM [11].

$20-25 \%$ of fetal congenital abnormalities come from chromosomal abnormalities or single gene abnormalities. $65-75 \%$ of fetal congenital abnormalities occur due to several factors, such as Mother's Infection (CMV, Syphilis, Rubella, Toxoplasma), Maternal Disease (DM, Epilepsy, Alcohol Consumption), and Radiation [12]. 
Table 4.13 Distribution of Congenital Congenital Abnormalities Based on Distance of Pregnancy at HAM Hospital

\begin{tabular}{lll}
\hline Distance of Pregnancy & Frekuensi & $\%$ \\
\hline First Pregnancy & 17 & 26,2 \\
$10-15$ months & 7 & 10,8 \\
$16-20$ months & 9 & 13,8 \\
$21-25$ months & 8 & 12,3 \\
$26-30$ months & 7 & 10,8 \\
$30-31$ months & 6 & 9,2 \\
$>31$ months & 11 & 16,9 \\
\hline Total & 65 & 100 \\
\hline
\end{tabular}

Table 4.14 Distribution of Congenital Congenital Abnormalities Based on Distance of Pregnancy at USU Hospital

\begin{tabular}{lll}
\hline Distance of Pregnancy & Frequency & $\%$ \\
\hline First Pregnancy & 10 & 37,0 \\
$10-15$ months & 5 & 18,5 \\
$16-20$ months & 5 & 18,5 \\
$21-25$ months & 1 & 3,7 \\
$26-30$ months & 3 & 11,1 \\
$30-31$ months & 2 & 7,4 \\
$>31$ months & 1 & 3,7 \\
\hline Total & 27 & 100 \\
\hline
\end{tabular}

Based on tables 4.13 and 4.14 above, it can be seen that the proportion of congenital abnormalities based on the distance of pregnancy in the first pregnancy is 27 (29.34\%), at a distance of 10-15 months of pregnancy, 12 (13.04\%) are obtained, 16-20 months are 14 (15.21\%), 21-25 months were 9 (9.7\%), 26-30 months were 10 (10.8\%), 30-31 months were $8(8.6 \%)$, and $>31$ month is $12(13.04 \%)$. 
Table 4.15 Distribution of Occurrences of Congenital Congenital Based on Nutrition Status at HAM Hospital

\begin{tabular}{lll}
\hline Nutrition Status & Frekuensi & $\%$ \\
\hline Good & 24 & 36,9 \\
Poor & 41 & 63,1 \\
\hline Total & 65 & 100
\end{tabular}

Table 4.16 Distribution of Occurrences of Congenital Congenital Based on Nutrition Status at USU Hospital

\begin{tabular}{lcc}
\hline Nutrition Status & Frekuensi & $\%$ \\
\hline Good & 12 & 44,4 \\
Poor & 25 & 55,6 \\
\hline Total & 27 & 100 \\
\hline
\end{tabular}

Based on tables 4.15 and 4.16 above it can be seen that the occurrence of congenital abnormalities in the fetus based on good nutritional status is $36(39.13 \%)$ and based on poor nutritional status is $66(71.7 \%)$.

Poor nutritional status in the third trimester affects the occurrence of fetal congenital abnormalities at Jagir Hospital in Surabaya with an incidence of $14.7 \%$, it can be concluded that good nutritional status can increase the weight of newborns [13].

Table 4.17 Distribution of Congenital Abnormalities Based on History of Infection at HAM

\section{Hospital}

\begin{tabular}{lll}
\hline History of Infection & Frequency & $\%$ \\
\hline CMV & 4 & 36,9 \\
HSV & 7 & 10,8 \\
Syphilis & 8 & 12,3 \\
Toxoplasmosis & 4 & 6,2 \\
None & 42 & 64,6 \\
\hline Total & 65 & 100 \\
\hline
\end{tabular}


Table 4.18 Distribution of Congenital Abnormalities Based on History of Infection at USU Hospital

\begin{tabular}{llc}
\hline Riwayat Infeksi & Frequency & $\%$ \\
\hline CMV & 1 & 3,7 \\
HSV & 3 & 11,1 \\
Syphilis & 4 & 15 \\
Toxoplasmosis & 2 & 7,4 \\
None & 17 & 63 \\
\hline Total & 27 & 100 \\
\hline
\end{tabular}

Based on tables 4.17 and 4.18 it can be seen that the distribution of fetal congenital abnormalities based on a history of CMV infection of 5 (5.43\%), history of HSV infection of 10 (10.8\%), history of syphilis infection as much as $12(13.04 \%)$, history of toxoplasmosis infection 6 (6.52\%), and mothers who did not experience a history of infection were 59 (64.13\%).

One case of condyloma lata has been reported as a clinical manifestation of secondary syphilis in a 17-year-old female patient with a 24-week first pregnancy. Syphilis in pregnancy provides the same manifestations as syphilis infection in general. Syphilis causes various effects on the mother and fetus if not handled properly [14].

Cytomegalovirus (CMV) infections are the most congenital infections and cause high morbidity in newborns. CMV transmission can occur horizontally (from one person to another) or vertically (from mother to fetus). Most children born with congenital CMV infection are asymptomatic at birth. Children who show symptoms of congenital CMV infection at birth only range from $7-10 \%[15]$.

Table 4.19 Distribution of Congenital Abnormalities Based on Congenital History at HAM Hospital

\begin{tabular}{lll}
\hline Congenital History & Frequency & $\%$ \\
\hline CHD & 6 & 9,2 \\
Hydrocephalus & 3 & 4,6 \\
Microcephalus & 5 & 7,7 \\
Omphalocele & 4 & 6,2 \\
Nonen & 47 & 72,3 \\
\hline Total & 65 & 100 \\
\hline
\end{tabular}


Table 4.20 Distribution of Congenital Abnormalities Based on Congenital History at USU Hospital

\begin{tabular}{lcc}
\hline Congenital History & Frequency & $\%$ \\
\hline CHD & 2 & 7,4 \\
Hydrocephalus & 1 & 3,7 \\
Microcephalus & 2 & 7,4 \\
Omphalocele & 3 & 11,1 \\
None & 19 & 70,4 \\
\hline Total & 27 & 100 \\
\hline
\end{tabular}

Based on tables 4.19 and 4.20 above, the proportion of congenital abnormalities based on congenital history of CHD is 8 (8.69\%), Hydrocephalus 4 (4.34\%), Microcephaly 7 (7.6\%), Omphalocele 7 (7.6\%), and those without a history of congenital disease were $66(71.7 \%)$.

A pregnancy history of congenital abnormalities, direct marriage, and previous medical history are important factors in the occurrence of fetal congenital abnormalities [16].

Table 4.21 Distribution of Congenital Abnormalities Based on Cigarette Consumption at HAM

\section{Hospital}

\begin{tabular}{lcc}
\hline Cigarette Consumption & Frequency & $\%$ \\
\hline Yes & 29 & 44,6 \\
No & 36 & 55,4 \\
\hline Total & 65 & 100 \\
\hline
\end{tabular}

Table 4.22 Distribution of Congenital Abnormalities Based on Cigarette Consumption at USU

\section{Hospital}

\begin{tabular}{lcc}
\hline Cigarette Consumption & Frequency & $\%$ \\
\hline Yes & 15 & 55,2 \\
No & 12 & 44,8 \\
\hline Total & 27 & 100 \\
\hline
\end{tabular}

Based on tables 4.21 and 4.22 the proportion of fetal congenital abnormalities based on history of consuming cigarettes was obtained as many as $44(47.8 \%)$ while those who did not consume 
as many as 48 (52.17\%). There are mothers who do not smoke more found with congenital abnormalities of the fetus, but contrary to existing theories. According to the researchers' view, mothers who experience fetal congenital abnormalities in RSUP HAM and USU Hospital are not only caused by one risk factor, but many risk factors. It's just a risk factor for cigarette consumption is not too influential for this study sample. Based on the theory, cigarette consumption in pregnant women increases the occurrence of fetal congenital abnormalities.

Cigarette consumption during pregnancy can cause complications such as low birth weight babies and intra-uterine growth restriction. The incidence of developmental disorders such as asthma, neurologic disorders, heart disease, and obesity in children increases because mothers smoke during pregnancy. pregnancy also increases the incidence of premature, congenital DM, and Sectio during childbirth [17].

The Zhao study (2019) reported that parents who smoke and mothers who are pregnant have negative effects such as an increased incidence of Atrial Fibrillation and Heart Failure, which originate from the parents' genes and cause Congenital Heart Disease [18].

Table 4.23 Distribution of Occurrence of Congenital Congenital Based on Socio-Economic in HAM Hospital

\begin{tabular}{llc}
\hline Socio-Economic & Frekuensi & $\%$ \\
\hline Upper & 20 & 30,8 \\
Mid & 23 & 35,4 \\
Lower & 22 & 33,8 \\
\hline Total & 65 & 100 \\
\hline
\end{tabular}

Table 4.24 Distribution of Occurrence of Congenital Congenital Based on Socio-Economic in HAM Hospital

\begin{tabular}{lll}
\hline Socio-Economic & Frequency & $\%$ \\
\hline Upper & 8 & 29,6 \\
Mid & 9 & 33,3 \\
Lower & 10 & 37 \\
\hline Total & 27 & 100 \\
\hline
\end{tabular}

Based on tables 4.23 and 4.24 the distribution of fetal congenital abnormalities based on socioeconomic upper classes was obtained as many as 28 (30.43\%), based on middle 
socioeconomic as many as $32(34.7 \%)$, and based on lower socioeconomic factors was 32 (34.7 $\%)$.

Fetal congenital abnormalities are still unknown. Socio-economic imbalance affects the occurrence of fetal congenital abnormalities and can be used as a guide, several previous studies have proven the nutritional causes of NTD, and also explain the socio-economic potential in environments such as the industrial environment. Socio-economic is a risk factor for low birth weight, perinatal, neonatal, and postneonatal mortality [19].

\section{Conclusion}

Based on the results of data analysis and discussions that have been carried out in this study, the conclusions can be written as follows:

1. The number of patients with fetal congenital abnormalities at the Haji Adam Malik General Hospital (65 Patients) and the University Hospital of North Sumatra (27 Patients) in 2017 - 2019 is 92 .

2. Characteristics of mothers of patients experiencing fetal congenital abnormalities can be categorized into:

- Mother's age: 25-40 years there are 60 patients while 18-25 years there are 32 patients

- Age of Pregnancy: 36-39 Months there are 63 Patients while 33-35 Months there are 29 Patients.

- Disease History: There are 53 patients with a history of illness while 39 patients have no history.

- GPA: Gestation 127 patients (29.3\%), Gestation 245 patients (48.9\%), and Gestation> 320 patients (21.7\%). Partus 0 rates were 35 patients (38\%), Partus 143 patients (46.7\%), and Partus 2 were 14 patients (15.2\%). Abortion rate 076 patients (82.6\%) and Abortion rate 116 patients $(17.3 \%)$.

- Distance of Pregnancy: In the first pregnancy is 27 (29.34\%), at the distance of pregnancy 10-15 months get 12 (13.04\%), 16-20 months as many as 14 (15.21\%), 21-25 months 9 (9.7\%), 26-30 months were 10 (10.8\%), 30-31 months were 8 (8.6\%), and> 31 months were 12 $(13.04 \%)$.

- Nutritional Status: Good nutritional status is $36(39.13 \%)$ and based on poor nutritional status is $66(71.7 \%)$.

- History of Infection: Distribution of fetal congenital abnormalities based on a history of CMV infection of 5 (5.43\%), history of HSV infection of 10 (10.8\%), history of syphilis infection 
of $12(13.04 \%)$, history of toxoplasmosis infection 6 (6.52\%), and 59 mothers (without a history of infection) $(64.13 \%)$.

- Congenital history: The proportion of fetal congenital abnormalities based on a congenital history of CHD is 8 (8.69\%), hydrocephalus of 4 (4.34\%), microcephaly 7 (7.6\%), omphalocele 7 (7.6\%), and no history of congenital disease was $66(71.7 \%)$.

- Cigarette Consumption: The proportion of fetal congenital abnormalities based on history of consuming cigarettes was obtained as many as $44(47.8 \%)$ while those who did not consume cigarettes were $48(52.17 \%)$.

- Socio-Economic: Distribution of the occurrence of fetal congenital disorders based on socioeconomic classes obtained as many as $28(30.43 \%)$, based on middle socioeconomic as many as $32(34.7 \%)$, and based on lower socioeconomic is $32(34.7 \%)$.

- Mode of delivery: Distribution of fetal congenital abnormalities based on normal delivery was found to be $38(41.3 \%)$ and Caesarean Sectio as much as 54 (58.7\%).

3. The most influential risk factors for fetal congenital disorders are maternal age, disease history, infection history, and poor nutritional status.

4. There are no results that can prove that Pregnancy History affects the occurrence of fetal congenital abnormalities

\section{REFERENCES}

[1] Effendi, S.H., E. Indrasanto. 2008. Buku Ajar Neonatologi $1^{\text {st }}$ Ed. Badan Penerbit IDAI, Jakarta.

[2] Unnimon K. Devassy, Danasegaran M, Kumar Sai Sailesh, Soumya Mishra, Udaya Kumar Reddy, Antony N J. Congenital Anomalies Among Newborns. Bali Medical Journal. 2015. https://www.balimedicaljournal.org/index.php/bmj/article/viewFile/104/136

[3] Birth Defects in South-East Asia A public health challenge. 2013. http://apps.searo.who.int/PDS_DOCS/B4962.pdf

[4] Conway, D. H. 2008. Prevalence of Congenital Anomalies in Infants with in UteroExposure to Antiretrovirals: IMPAACT P1025. National Institute of Health, Philladelphia.

[5] Taksande, A., Vilhekar, K., Chaturvedi, P., \& Jain, M. (2010). Congenital malformations at birth in Central India: A rural medical college hospital based data. Indian Journal of Human Genetics, 16(3), 159. doi:10.4103/0971-6866.73412

[6] Sofian, Amru, 2012. Sinapsis Obstetric Rustam Muckhtar. EGC. Jakarta. Office of Communications. Eunice Kennedy Shriver National Institute of Child Health and Human Development, 2017. https://www.nichd.nih.gov/health/topics/birthdefects 
[7] Manuaba, Ida Bagus Gde. 2012. Ilmu Kebidanan, Penyakit Kandungan, dan KB untuk Pendidikan Bidan, Edisi 2. Jakarta : EGC

[8] Prabawa, M. 1998. Kejadian Bayi Lahir dengan Kelainan Kongenital.Tesis Program Pendidikan Dokter Spesialis FK UNDIP. Semarang. http://eprints.undip.ac.id/12179/1/1998PPDS510.pdf

[9] Glinianaia, S.V., P.W. Tennant, J. Rankin.2017. Risk estimates of recurrent congenital anomalies in the UK: a population-based register study. BMC Med. 2017;15(1):20. Published 2017 Jan 31. doi:10.1186/s12916-017-0789-5

[10] Maharani TK, 2013. Faktor-Faktor Yang Berpengaruh Terhadap Terjadinya Kelainan Kongenital Sistem Urogenital Pada Neonatus. Karya Tulis Ilmiah FK UNDIP. Semarang. http://eprints.undip.ac.id/44182/2/BAB_I.pdf

[11] Talisma K. (2017). Congenital anomalies among the Babies of Diabetic Mothers with Uncontrolled Blood Sugar - A Study in Tertiary Hospital.

[12] Ernawati, R., Purwaka B. T., Prasetyo B., 2017. Nutritional Status of Third Trimester Pregnant Women Correlates Positively With Birth Weight. Majalah Obstetri \& Ginekologi, Vol.25 No. 2 August 2017 : 41 - 47. Department of Obstetric and Gynecologic, Faculty of Medicine, Universitas Airlangga, Dr. Soetomo Hospital, Surabaya.

[13] Batan, N. W., Puspawati, D. 2017. Kondiloma Lata Sebagai Manifestasi Klinis Sekunder Pada Kehamilan Trimester Kedua. MEDICINA 2019, Volume 50, Number 2: 249-254.

[14] Pratama, B. F. 2018. Infeksi Cytomegalovirus Kongenital. Jurnal Kesehatan Melayu, Vol.1 No. 2. Artikel info: Online published first 25 April 2018; Received 26 September 2017; Accepted 31 Maret 2018. DOI: https://doi.org/10.26891/jkm.v1i2.2018.114-117

[15] Sozan K. Ameen, Shahla Kareem Alalaf, Nazar P. Shabila. Pattern of congenital anomalies at birth and their correlations with maternal characteristics in the maternity teaching hospital, Erbil city, Iraq. BMC Pregnancy and Childbirth (2018). DOI: https://doi.org/10/1186/s12884-018-2141-2।

[16] Kessous, R., Wainstock, T., \& Sheiner, E. (2019). Smoking during pregnancy as a possible risk factor for pediatric neoplasms in the offspring: A population-based cohort study. Addictive Behaviors, 90, 349-353. doi:10.1016/j.addbeh.2018.11.039

[17] Lijuan Zhao, Lizhang Chen, Tubao Yang, Lesan Wang, Tingting Wang, Senmao Zhang, Letao Chen, Ziwei Ye, Zan Zheng and Jiabi Qin. Parental smoking and the risk of congenital heart defects in offspring: An updated meta-analysis of observational studies. European Journal of PreventiveCardiology. 2019. DOI: $10.1177 / 2047487319831367$. 
[18] M Vrijheid, H Dolk, D Stone, L Abramsky, E Alberman, J E S Scott. 2000. Socioeconomic inequalities in risk of congenital anomaly. Arch Dis Child 2000; 82 :349-352.Arch Dis Child: first published as 10.1136/adc.82.5.349 on 1 May 2000. 